\title{
A Study to Assess the Effectiveness of Planned Teaching Programme on Knowledge Regarding Depression Among Care Givers of Depressive Patients in Selected Hospitals of City.
}

\author{
${ }^{(1)}$ L.H. Sarode ${ }^{(2)}$ N.M. Bhondge \\ (1) Dept. of Psychiatric Nursing, Asharam College of Nursing, Kamptee, Nagpur. India \\ ${ }^{(2)}$ Dept. of Mathematics, Priyadarshini Indira Gandhi College of Engineering, Nagpur. India
}

\begin{abstract}
In this paper we assess the pre test and post test knowledge regarding depression among care givers of depressive patients in selected hospitals of city. Then we assess the effectiveness of planned teaching programme on depression among care givers of depressive patients. We find out the significant difference between pre test and post test knowledge score regarding depression among care givers of depressive patients.

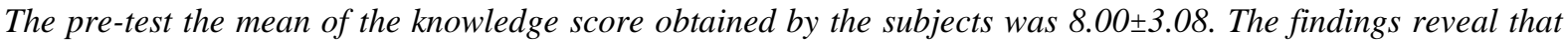
in pre test $63.33 \%$ of caregivers of depressive patients were having average knowledge, $23.33 \%$ had were having good, $10 \%$ poor and $3.33 \%$ had very good level of knowledge score. The minimum score in pre test was 2 and the maximum score was 19. In the post test mean of the knowledge score was 20.61 \pm 2.40 . It reveals that in post test $25 \%$ of caregivers of depressive patients were having very good knowledge, $73.33 \%$ were having excellent and only $1.67 \%$ were having good level of knowledge score. The minimum score in post test was 14 and the maximum score was 25. The levels of knowledge during the pre test and post test are compared to prove the effectiveness of planned teaching programme. Significance of difference at $5 \%$ level tested with paired 't' test and tabulated ' $t$ ' value is compared with calculated ' $t$ ' value. Also the calculated ' $p$ ' values are compared with acceptable ' $p$ ' value i.e. 0.05 . The care givers do not have knowledge regarding depression in pre test. There was a significant increase in the knowledge of subjects after the introduction of planned teaching. To find the effectiveness of planned teaching 't' test was applied and t value was calculated, post test score was significantly higher at 0.05 level than pre test score. Thus it was concluded that planned teaching on depression was effective.
\end{abstract}

Keywords: Planned teaching, t-test, p-value, care givers, depressive patient, and effectiveness.

\section{Introduction}

The $18^{\text {th }}$ century is fondly addressed by the Sociologists as the century of inventions, $19^{\text {th }}$ as the century of progress and $20^{\text {th }}$, the century of anxiety by extrapolation, the $21^{\text {st }}$ century is the century of depression. ${ }^{1}$ Depression is among the 20 most Common causes of morbidity and disability in India, leading to substantial decrease in quality of life and productivity. Depression is one of the most common psychological disorders affecting 340 million people in the world today. Accounting for a full 10\% productive years lost throughout the world. No one is immune from depression, as it occurs in people of all classes, all countries and all cultural settings. $^{2}$

World health Report (WHO, 2001) Defines Depression as a common Mental disorder that presents with depressed mood, loss of interest or pleasure, feelings of guilt or low self worth, disturbed sleep or appetite low energy and poor concentration. ${ }^{3}$ Depression is a disorder of major public health importance, in terms of its prevalence and the suffering, dysfunction, morbidity, and economic burden. Depression is more common in women than men. The report on Global Burden of Disease estimates the point prevalence of unipolar depressive episodes to be $1.9 \%$ for men and $3.2 \%$ for women, and the one-year prevalence has been estimated to be $5.8 \%$ for men and $9.5 \%$ for women. It is estimated that by the year 2020 if current trends for demographic and epidemiological transition continue, the burden of depression will increase to $5.7 \%$ of the total burden of disease and it would be the second leading cause of disability-adjusted life years (DALYs) ${ }^{4}$

An article published by Saldanha (2012) explains about the role played by one family member; and his health status can influence the health and functioning level of the rest of the family. When a member is Sick he would discontinue from his normal social activities. So the other family members have to undertake the care of the sick person. Care givers of depressive patients have high levels of expressed emotions including critical, hostile, or over involved attitudes. ${ }^{5}$ Care givers play an important and essential role in the care of patients with depressive disorders. According to Fink social support is an important factor in care giving of severely mentally ill persons. It plays a significant role in the care givers effective management of the has been shown to affect family well being. ${ }^{6}$ 
Care givers of people with depressive disorder many experience a different quality of burden than is seen with other illnesses. A better understanding of their concern is necessary to improve the training of care givers. perception of care givers about depressive disorder have important effects on levels of burden experienced care giver burden is associated with depression, which affects patients recovery by adding stress to the living environment. ${ }^{7}$ According to WHO survey, it reported the problem of caregivers of psychiatric patients. It is stated that $51 \%$ of all caregivers are suffering from stress. $25 \%$ of caregivers have no job satisfaction and $43 \%$ caregivers are expecting to reduce their working hours.

In this study, assess means to find out the value of planned teaching programme

1. Effectiveness means to the extent to which plan teaching programme had achieved the desired effect on knowledge of care givers regarding depression.

2. Planned teaching refers to, systematically providing information regarding depression among the care givers of depressive patients.

3. Depression is a person who is suffering from depressed mood loss of interest, reduced energy which leads to increased fatigability and diminished activity.

4. Care givers referred to any one of the patients close relatives (parents, in-laws, cousin, spouse, sibling, son or daughter) who is staying with or visiting the patient frequently in the hospital.

5. Knowledge it refers to the process of giving systematic information about depression.

\section{Hypothesis:}

H0:- There will be no significant difference between pre test and post test knowledge score regarding depression among care givers of depressive patients in selected hospitals of the city.

$\mathrm{H}_{1}$ :- There will be a significant difference between pre test and post test knowledge score regarding depression among care givers of depressive patients in selected hospitals of the city.

\section{The Objectives Of The Study Were:}

1. To assess the existing knowledge regarding depression among care givers of depressive patients in selected hospitals of city.

2. To assess the effectiveness of planned teaching programme on depression among care givers of depressive patients in selected hospitals of city.

3. To associate post test knowledge score with selected demographic variables.

\section{Organization Of Findings:}

The analysis and interpretation of the observations are given in the following section:

Section A- Distribution of caregivers of depressive patients with regards to demographic variables.

Section B- Assessment of pre test knowledge regarding depression among care givers of depressive patients in selected hospitals of city.

Section C- Assessment of post test knowledge regarding depression among care givers of depressive patients in selected hospitals of city.

Section D- Evaluation of effectiveness of planned teaching programme on depression among care givers of depressive patients in selected hospitals of the city.

Section E- Association of knowledge score in relation to demographic variables.

Section A

Distribution of caregivers of depressive patients with regards to demographic variables.

This section deals with distribution of caregivers of depressive patients with regards to their demographic variables. A convenient sample of 60 subjects was drawn from the study population, who were selected from selected hospitals of city. The data obtained to describe the sample characteristics including age, gender, type of family, education, occupation and source of information respectively.

Table-1: percentage wise distribution of caregivers according to their demographic characteristics.

\begin{tabular}{|l|l|l|}
\hline Demographic Variables & Frequency & Percentage (\%) \\
\hline Age(yrs) & 6 & 10.0 \\
\hline $18-26$ & 10 & 16.7 \\
\hline $27-35$ & 25 & 41.7 \\
\hline $36-44$ & 13 & 21.7 \\
\hline $45-53$ & 6 & 10.0 \\
\hline $54-62$ & 21 & 35.0 \\
\hline Gender & 39 & 65.0 \\
\hline Male & \multicolumn{2}{|l|}{} \\
\hline Female & 20 & 33.3 \\
\hline Type of family &
\end{tabular}




\begin{tabular}{|c|c|c|}
\hline Joint & 40 & 66.7 \\
\hline \multicolumn{3}{|l|}{ Education } \\
\hline Primary & 15 & 25.0 \\
\hline Secondary & 21 & 35.0 \\
\hline Higher Secondary & 18 & 30.0 \\
\hline Graduate & 5 & 8.3 \\
\hline PG & 1 & 1.7 \\
\hline Other & 0 & 0.00 \\
\hline \multicolumn{3}{|l|}{ Occupation } \\
\hline Housewife & 28 & 46.7 \\
\hline Private Employee & 16 & 26.7 \\
\hline Govt. Employee & 7 & 11.7 \\
\hline Others & 9 & 15.0 \\
\hline \multicolumn{3}{|c|}{ Source of information } \\
\hline Mass Media & 5 & 8.3 \\
\hline Health Personnel & 30 & 50.0 \\
\hline Friends & 7 & 11.7 \\
\hline Relatives & 12 & 20.0 \\
\hline Others & 6 & 10.0 \\
\hline
\end{tabular}

Distribution of caregivers of depressive patients in relation to their age shows that $10 \%$ of them were belonging to the age of $18-26$ years, $16.7 \%$ in $27-35$ years, $41.7 \%$ in $36-44$ years, $21.7 \%$ in 45.53 years and $10 \%$ in 54-62 years respectively.Distribution of caregivers of depressive patients according to their gender reveals that $35 \%$ of them were males and $65 \%$ were females. Distribution of caregivers of depressive patients according to their type of family shows that $33.3 \%$ were belonging to nuclear and $66.7 \%$ in joint families respectively. Distribution of caregivers of depressive patients according to their educational status shows that $25 \%$ of them were having education up to primary, $35 \%$ up to secondary, $30 \%$ up to higher secondary, $8.3 \%$ were graduates and only $1.7 \%$ was postgraduate respectively. Distribution of caregivers of depressive patients according to their occupational status shows that $46.7 \%$ of them were housewife, $26.7 \%$ were private employees, $11.7 \%$ were doing government jobs and $15 \%$ were doing other type of work. Distribution of caregivers of depressive patients in relation to source of information regarding depression shows that $8.3 \%$ of them had information from mass media, $50 \%$ from health personnel, $11.7 \%$ from friends, $20 \%$ from relatives and $10 \%$ had information from other sources respectively.

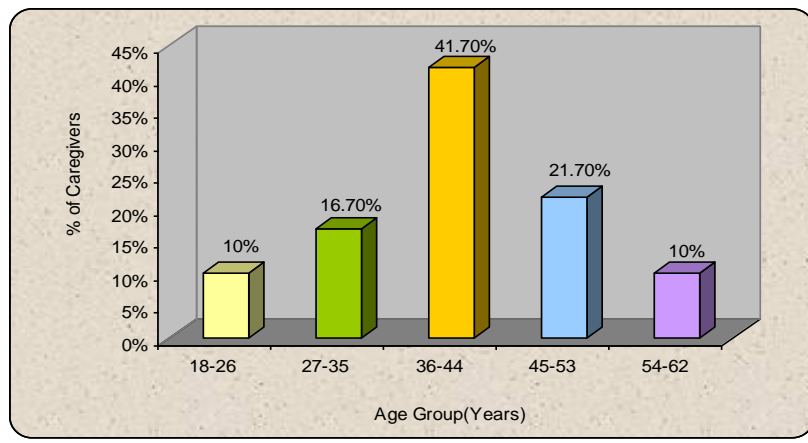

Graph 1: Percentage wise distribution of according to their age (years).

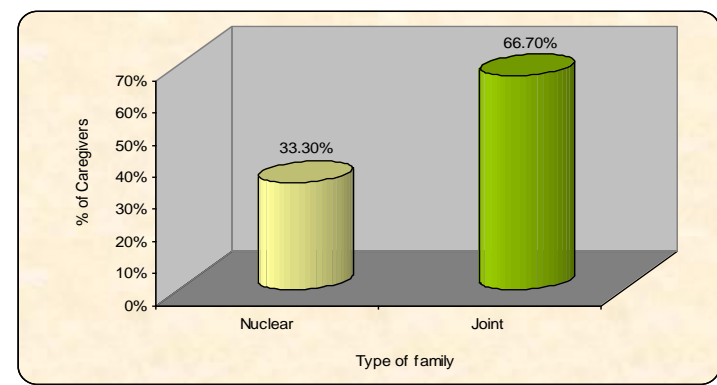

Graph 3: Percentage wise distribution of Caregivers according to their type of family

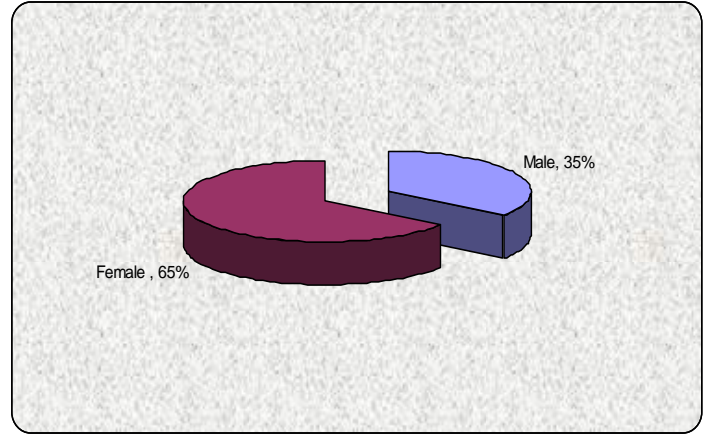

Graph 2: Percentage wise distribution of caregivers Caregivers according to their gender

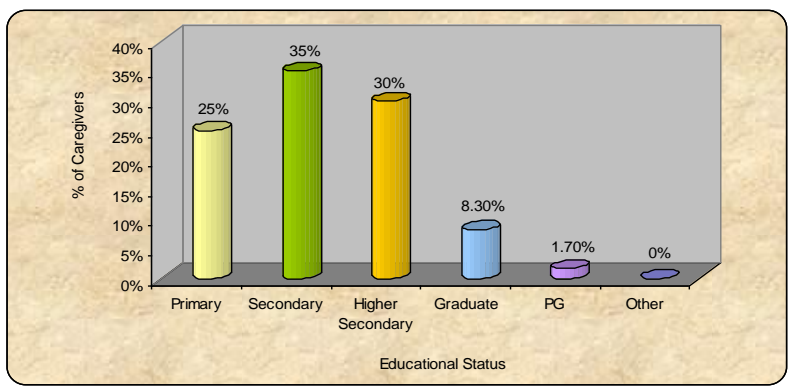

Graph 4: Percentage wise distribution of caregivers according to their education 


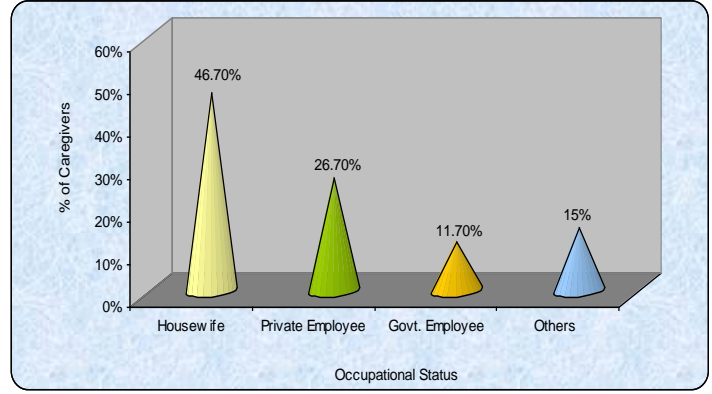

Graph 5: Percentage wise distribution of caregivers according to their occupation

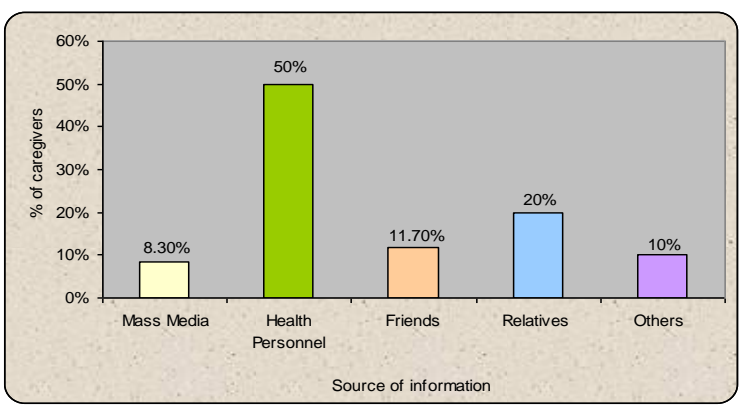

Graph 6: Percentage wise distribution of caregivers according to their source of information.

\section{Section B}

Assessment of pre test knowledge regarding depression among care givers of depressive patients.

This section deals with the assessment of pre test knowledge regarding depression among care givers of depressive patients in selected hospitals of city.

Table 2: General assessment with pre test

\begin{tabular}{|l|l|l|l|l|}
\hline Level of knowledge score & Score range & Percentage score & Pre Test \\
\cline { 3 - 5 } & & & Frequency & Percentage \\
\hline Poor & $0-5$ & $0-19 \%$ & 6 & 10.00 \\
\hline Average & $6-10$ & $20-39 \%$ & 38 & 63.33 \\
\hline Good & $11-15$ & $40-59 \%$ & 14 & 23.33 \\
\hline Very Good & $16-20$ & $60-79 \%$ & 2 & 3.33 \\
\hline Excellent & $21-25$ & $\geq 80 \%$ & 0 & 0.00 \\
\hline Minimum score & 2 & \multicolumn{3}{|l}{} \\
\hline Maximum score & 19 & \multicolumn{3}{|l}{} \\
\hline Mean score & $8.00 \pm 3.08$ & \\
\hline Mean \% & $31.90 \pm 12.54$ & \\
\hline
\end{tabular}

Above table shows that in pre test $6(10 \%)$ poor knowledge, $38(63.33 \%)$ of caregivers of depressive patients were having average knowledge, $23.33 \%$ had were having good and $3.33 \%$ had very good level of knowledge score. The minimum score in pre-test was 2 and the maximum score was 19, the mean score for the pre-test was $8.00 \pm 3.08$.

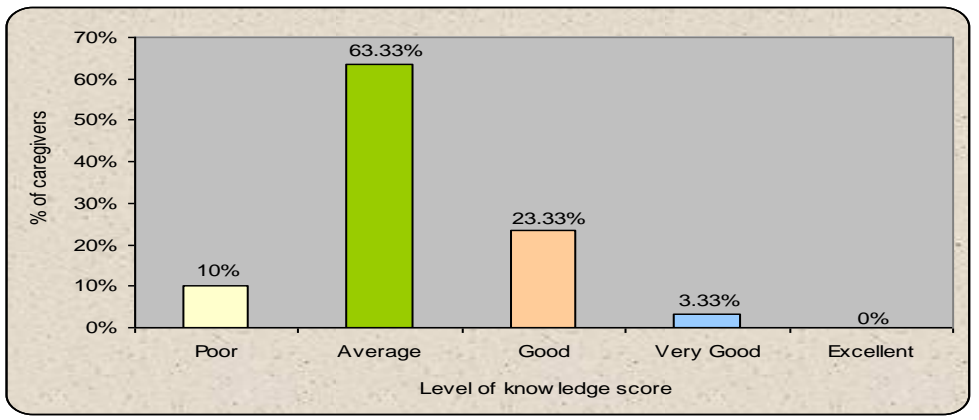

Graph 7: General assessment with pre test

Section C

Assessment of post test knowledge regarding depression among care givers of depressive patients.

Table 3: General assessment with post test

\begin{tabular}{|l|l|l|l|l|}
\hline $\begin{array}{l}\text { Level of knowledge } \\
\text { score }\end{array}$ & Score range & Percentage score & Post Test & Percentage \\
\cline { 3 - 5 } & & & Frequency & 0.00 \\
\hline Poor & $1-5$ & $0-19 \%$ & 0 & 0.00 \\
\hline Average & $6-10$ & $20-39 \%$ & 0 & 1.67 \\
\hline Good & $11-15$ & $40-59 \%$ & 1 & 25.00 \\
\hline Very Good & $16-20$ & $60-79 \%$ & 45 & 73.33 \\
\hline Excellent & $21-25$ & $\geq 80 \%$ & & \\
\hline Minimum score & 14 & \multicolumn{3}{l}{} \\
\hline Maximum score & 25 & \multicolumn{3}{l}{} \\
\hline Mean score & $20.61 \pm 2.40$ & & \\
\hline Mean \% & $82.46 \pm 9.60$ &
\end{tabular}


The above table shows that in post test $15(25 \%)$ of caregivers of depressive patients were having very good knowledge, $73.33 \%$ were having excellent and only $1.67 \%$ were having good level of knowledge score. The minimum score in post-test was 14 and the maximum score was 25 , the mean score for the posttest was $20.61 \pm 2.40$

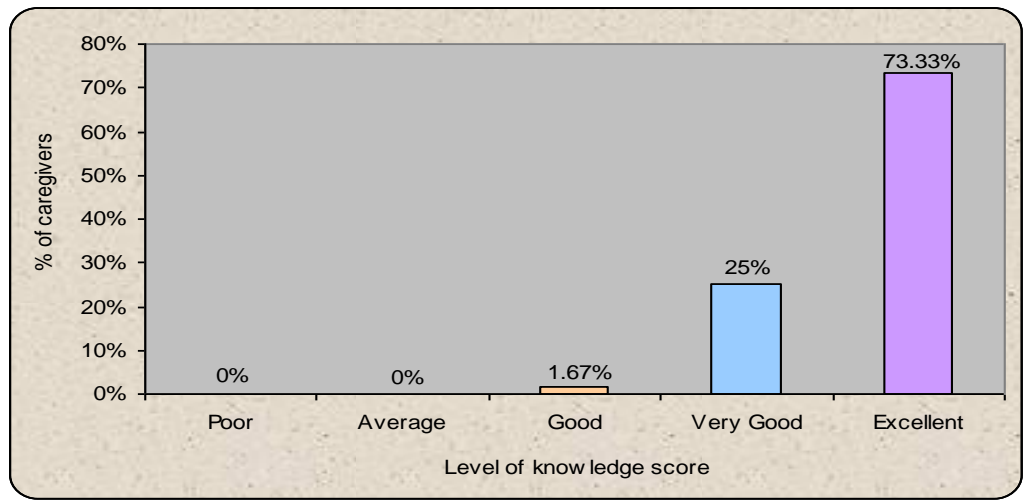

Graph 8: General assessment with post test

Section-D

Evaluation of effectiveness of planned teaching programme on depression among care givers of depressive patients in selected hospitals of the city.

This section deals with the effectiveness of planned teaching programme on knowledge regarding depression among care givers of depressive patients in selected hospitals of city. The hypothesis is tested statistically with area wise distribution of pre test and post test mean and standard deviation mean difference in pre and post test knowledge score. The levels of knowledge during the pre test and post test are compared to prove the effectiveness of planned teaching programme. Significance of difference at $5 \%$ level of significance is tested with student's paired ' $t$ ' test and tabulated ' $t$ ' value is compared with calculated ' $t$ ' value. Also the calculated 'p' values are compared with acceptable 'p' value i.e. 0.05 .

Table 4: Assessment of effectiveness of planned teaching programme knowledge scores regarding depression among care givers of depressive patients $n=60$

\begin{tabular}{|l|l|l|l|l|l|l|}
\hline Overall & Mean & SD & SE & Mean Percentage & t-value & p-value \\
\cline { 1 - 5 } Pre Test & 8.23 & 3.14 & 0.40 & 32.93 & \multirow{2}{*}{22.03} & S.000 \\
\cline { 1 - 5 } Post Test & 20.61 & 2.40 & 0.31 & 82.46 & & S $<05$ \\
\hline
\end{tabular}

This table shows the comparison of pre-test and post test knowledge scores regarding depression among caregivers of depressive patients. Mean, standard deviation and mean percentage score values are compared and student's paired test is applied at 5\% level of significance. The tabulated value for $n=60-1$ i.e 59 degrees of freedom was 1.98 . The calculated values were 22.03 respectively for the knowledge regarding depression. The calculated ' $t$ ' value are much higher than the tabulated value at $5 \%$ level of significance which is statistically acceptable level of significance. In addition the calculated ' $p$ ' values for knowledge regarding depression were 0.000 which is ideal for any population. Hence it is statistically interpreted that the planned teaching programme regarding depression was effective. Thus the $\mathrm{H}_{1}$ is accepted.

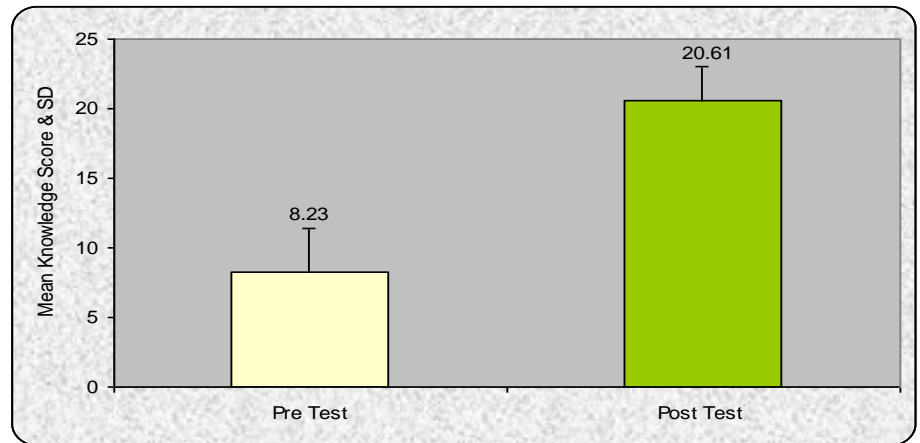

Graph 9: Significance of difference between knowledge score in pre and post test of caregivers of depressive patients in relation to knowledge regarding depression 


\section{Section E}

Association of knowledge score in relation to demographic variables.

Table 5: Significance of difference on knowledge of depression in relation to age. $\mathrm{n}=60$

\begin{tabular}{|l|l|l|l|l|}
\hline Age (yrs) & $\begin{array}{l}\text { No. of caregivers of } \\
\text { depressive patients }\end{array}$ & $\begin{array}{l}\text { Mean post knowledge } \\
\text { score }\end{array}$ & F-value & p-value \\
\hline $18-26$ & 6 & $21.16 \pm 1.47$ & 0.86 & 0.49 \\
\cline { 1 - 2 } $27-35$ & 10 & $20.80 \pm 2.97$ & & NS,p $>0.05$ \\
\cline { 1 - 2 }-44 & 25 & $21.04 \pm 2.49$ & \\
\cline { 1 - 3 } $54-62$ & 13 & $19.69 \pm 2.21$ & \\
\hline
\end{tabular}

This table shows the association of post test knowledge scores with the age of caregivers of depressive patients. The tabulated ' $F$ ' values was $2.52(\mathrm{DF}=4,59)$ which is higher than the calculated ' $F$ ' i.e. 0.86 at $5 \%$ level of significance. Also the calculated ' $p$ ' $=0.49$ which was much higher than the acceptable level of significance i.e. ' $p$ ' $=0.05$. Hence it is interpreted that the age of the care givers of depressive patients is not associated with their post test knowledge scores.

Table 6: Significance of difference on knowledge of depression in relation to gender. $n=60$

\begin{tabular}{|l|l|l|l|l|}
\hline Gender & $\begin{array}{l}\text { No. of caregivers of } \\
\text { depressive patients }\end{array}$ & $\begin{array}{l}\text { Mean post knowledge } \\
\text { score }\end{array}$ & t-value & p-value \\
\hline Male & 21 & $20.52 \pm 1.77$ & 0.21 & 0.82 \\
\hline Female & 39 & $20.66 \pm 2.69$ & & NS,p $>0.05$ \\
\hline
\end{tabular}

This table shows the association of post test knowledge scores with the gender of caregivers of depressive patients. The tabulated ' $t$ ' values was $1.98(\mathrm{df}=58)$ which is higher than the calculated' $t$ ' i.e. 0.21 at $5 \%$ level of significance. Also the calculated ' $p$ ' $=0.82$ which was much higher than the acceptable level of significance i.e. ' $p '=0.05$. Hence it is interpreted that the gender of the caregivers of depressive patients is not associated with their post test knowledge scores.

Table7: Significance of difference on knowledge of depression in relation to type of family.n=60

\begin{tabular}{|l|l|l|l|l|}
\hline Type of family & $\begin{array}{l}\text { No. of caregivers of } \\
\text { depressive patients }\end{array}$ & $\begin{array}{l}\text { Mean post knowledge } \\
\text { score }\end{array}$ & t-value & p-value \\
\hline Nuclear & 20 & $20.30 \pm 2.88$ & 0.71 & 0.47 \\
\hline Joint & 40 & $20.77 \pm 2.14$ & & NS,p $>0.05$ \\
\hline
\end{tabular}

This table shows the association of post test knowledge scores with the type of family of caregivers of depressive patients. The tabulated ' $t$ ' values was $1.98(\mathrm{df}=58)$ which is higher than the calculated ' $t$ ' i.e. 0.71 at $5 \%$ level of significance. Also the calculated ' $p$ ' $=0.47$ which was much higher than the acceptable level of significance i.e. ' $p$ ' $=0.05$. Hence it is interpreted that the type of family of the caregivers of depressive patients is not associated with their post test knowledge scores.

Table 8: Significance of difference on knowledge of depression in relation to education $n=60$

\begin{tabular}{|c|c|c|c|c|}
\hline Education & $\begin{array}{l}\text { No. of caregivers of } \\
\text { depressive patients }\end{array}$ & $\begin{array}{l}\text { Mean post } \\
\text { knowledge score }\end{array}$ & F-value & p-value \\
\hline Primary & 15 & $18.60 \pm 1.99$ & \multirow[t]{6}{*}{9.71} & \multirow{6}{*}{$\begin{array}{l}0.000 \\
\mathrm{~S}, \mathrm{p}<0.05\end{array}$} \\
\hline Secondary & 21 & $20.14 \pm 1.68$ & & \\
\hline Higher Secondary & 18 & $22 \pm 2.11$ & & \\
\hline Graduate & 5 & $23.40 \pm 1.67$ & & \\
\hline $\mathrm{PG}$ & 1 & $22 \pm 0.00$ & & \\
\hline Other & 0 & $0.00 \pm 0.00$ & & \\
\hline
\end{tabular}

This table shows the association of post test knowledge scores with the educational status of caregivers of depressive patients. The tabulated ' $F$ ' values was $2.52(\mathrm{df}=4,59)$ which is much less than the calculated ' $F$ ' i.e. 9.71 at $5 \%$ level of significance. Also the calculated ' $p$ ' $=0.000$ which was much less than the acceptable level of significance i.e. ' $p$ ' $=0.05$. Hence it is interpreted that the educational status of the care givers of depressive patients is statistically associated with their post test knowledge scores.

Table 9: Significance of difference on knowledge of Depression in relation to occupation. $n=60$

\begin{tabular}{|l|l|l|l|l|}
\hline Occupation & $\begin{array}{l}\text { No. of caregivers of } \\
\text { depressive patients }\end{array}$ & $\begin{array}{l}\text { Mean post knowledge } \\
\text { score }\end{array}$ & F-value & p-value \\
\hline Housewife & 28 & $20.10 \pm 2.57$ & 2.42 & 0.075 \\
\hline Private Employee & 16 & $20.75 \pm 1.87$ & & NS,p $>0.05$ \\
\cline { 1 - 3 } Govt. Employee & 7 & $22.71 \pm 1.25$ & & \\
\hline Others & 9 & $20.33 \pm 2.73$ & & \\
\hline
\end{tabular}


This table shows the association of post test knowledge scores with the occupational status of caregivers of depressive patients. The tabulated ' $F$ ' values was $2.76(\mathrm{df}=3,59)$ which is much higher than the calculated ' $F$ ' i.e. 2.42 at $5 \%$ level of significance. Also the calculated ' $p$ ' $=0.075$ which was much higher than the acceptable level of significance i.e. ' $p '=0.05$. Hence it is interpreted that the occupational status of the care givers of depressive patients is not associated with their post test knowledge scores.

Table 10: Significance of difference on knowledge of Depression in relation to source of information. $n=60$

\begin{tabular}{|l|l|l|l|l|}
\hline $\begin{array}{l}\text { Source ou } \\
\text { information }\end{array}$ & $\begin{array}{l}\text { No. of caregivers of } \\
\text { depressive patients }\end{array}$ & $\begin{array}{l}\text { Mean post knowledge } \\
\text { score }\end{array}$ & F-value & p-value \\
\hline Mass Media & 5 & $22 \pm 1.22$ & 0.55 & 0.70 \\
\hline Health Personnel & 30 & $20.30 \pm 2.56$ & & NS,p $>0.05$ \\
\hline Friends & 7 & $20.57 \pm 1.71$ & \\
\hline Relatives & 12 & $20.75 \pm 2.73$ & \\
\hline Others & 6 & $20.83 \pm 2.48$ & & \\
\hline
\end{tabular}

This table shows the association of post test knowledge scores with the source of information about depression of caregivers of depressive patients. The tabulated ' $F$ ' values was $2.52(\mathrm{df}=4,59)$ which is much higher than the calculated ' $F$ ' i.e. 0.55 at $5 \%$ level of significance. Also the calculated ' $p$ ' $=0.70$ which was much higher than the acceptable level of significance i.e. ' $p$ ' $=0.05$. Hence it is interpreted that the source of information of care givers of depressive patients is not associated with their post test knowledge scores.

\section{Implication Of The Study}

The findings of this study have implications for nursing practice, nursing education, nursing administration and nursing research.

\section{Nursing Services}

The care givers will be more vigilant and tactful in order to identify and provide knowledge regarding depression. When such planned teaching on depression are made which costs less and are more effective, it will provide sound and comprehensive knowledge to care givers. Planned teaching will serve as a ready reference material for the care givers. The information is particularly useful for care givers while caring for patients with depression. It will help the care givers to keep update knowledge regarding depression.

\section{Nursing Education}

The nursing curriculum is concerned with the preparation of the future nurses. The present study would help the nurses to understand the level of knowledge of care givers. The awareness on the critical situation and the prevention of its untoward effects should be a part of curriculum mental health nursing. They should be aware of the promotion activities for the care of client with depression. In service education should be conducted to improve knowledge of health professionals and nursing personals.

\section{Nursing Practice:}

Nurses have a prime important role for patient education in hospital and community. Every nurse practitioner must possess a prepared planned teaching, to teach the staff nurses regarding several aspects of care. Different A. V aids can be used in imparting knowledge to various categories of people. Nurses should conduct training programmes to impart knowledge regarding depression to the newly appointed nurses.

\section{Nursing Research:}

In Indian studies, there is scarce literature and research done on depression An untoward effect of providing knowledge is increasingly rapidly now- a days. This stresses a greater need for nursing research in these areas. Nursing is to care the individual from womb to tomb. Research studies should be conducted to assess the practices with respect to the knowledge. Prevention and intervention can be conducted for this vulnerable group.

\section{Nursing Administration:}

Nursing administration should implement outreach teaching to make the staff nurses aware about the depression. Necessary administration support should be provided to conduct several activities. Nursing administrators can identify the prevailing problems and organize in service education for the nurses of various departments. This will enhance the learning needs, planning and conducting educative programmes for staff nurses in the psychiatric setting. Nursing administrators can develop certain policies, prepare instructional media and organize continuing nursing education programmes related depression. 


\section{Recommendations}

A similar study can be replicated on a larger population for a generalization of findings. A comparative study can be carried out to find out the knowledge regarding depression. A similar study can be conducted by using a SIM (self instructional module) or a pamphlet or booklet.

\section{Conclusion}

After the detailed analysis, this study leads to the conclusion that the care givers do not have $100 \%$ knowledge regarding depression. There was a significant increase in the knowledge of subjects after the introduction of planned teaching. To find the effectiveness of planned teaching ' $t$ ' test was applied and $t$ value was calculated, post test score was significantly higher at 0.05 level than that of pre test score. Thus it was concluded that planned teaching on depression was found effective as a teaching strategy.Demographic variables did show a major role in influencing the pre test and post test knowledge score among the care givers.Hence, based on the above cited findings, it was concluded undoubtedly that the written prepared material by the investigator in the form of planned teaching helped the care givers to improve their knowledge on depression.

\section{References}

[1]. Andrade L, Caraveo-A.. Epidemiology of major depressive episodes: Results from the International Consortium of Psychiatric Epidemiology (ICPE) Surveys. Int JMethods Psychiatr. 2003;12(1):3-21. doi:10.1002/mpr.138. PMID 12830306

[2]. Kessler RC, Berglund P, Demler O, et al. The epidemiology of major depressive disorder: Results from the National Comorbidity Survey Replication(NCS-R).jama.2003;289(203):3095-105.

[3]. World Health Organization. The world health report 2001 - Mental Health: New Understanding, New Hope; 2001 [Retrieved 200810-19].

[4]. Lopez AD, Mathers CD, Ezzati M, Jamison DT, Murray CJ. Global Burden of Disease and Risk Factors. Washington: The World Bank; 2006.

[5]. Vebia N Vihang. Management of depression in primary care. Journal of Indian Medical Association 2012 Feb; 103(2): 68-70.

[6]. Ozgul.S.parental. Grief and serious mental illness. The Hindu online edition of India's National newspaper 2002 Sep 20 ; Sec.A:3 (Col.5)

[7]. Gada Manilal. Taioreptive in the primary care setting of India. Journal of the Indian Medical Association 2005 April; 105 (4): P 105-06.

[8]. Reddy MV, Chandrashekhar CR. Prevalence of mental and behavioural disorders in India: A metaanalysis. Indian J Psychiatry. 1998;40:149-5

[9]. Nandi DN, Banerjee G, Mukherjee SP, Ghosh A, Nandi PS, Nandi S. Psychiatric morbidity of a rural Indian community changes over a 20 year interval. British J Psychiatry. 2000;176:351-6. [PubMed]

[10]. Sethi BB, Prakash R. Depression in Industrial population. Indian J Psychiatry. 1979;21:359-61.

[11]. Poongothai S, Pradeepa R, Ganesan A, Mohan V. Prevalence of depression in a large urban South Indian population - The Chennai Urban Rural Epidemiology Study (CURES-70) PloS One. 2009;4:E7185.

[12]. Amin G, Shah S, Vankar GK. The prevalence and recognition of depression in primary care. Indian J Psychiatry. 1998;40:364-369

[13]. De'silva, D \& De'Silva, S.A preliminary study of the impact of long term psychotic disorder on patients families. Paper presentation 2006, University of Colombo.

[14]. Alen D Oslivie. The burden on informed care givers of people with bipolar disorder. Prevalence and Correlates of burden among care givers [serial online] 2005 April [cited 2007 August 25]; 22 (1): [25-32]

[15]. Anna Kristensson, Ekwall (2007), 'Older Caregivers' coping strategies and sense of coherence in relation to quality of life'. Journal of Advanced Nursing 57 (6): 584-596.

[16]. Sharma Suresh K. Nursing research and statistics. $1^{\text {st }}$ edition 2011, Elsevier publisher, printed at Harayana, page number: 70-73

[17]. [Anita Thapar, Stephan Collishaw, Daniel S Pine, Ajay K ThaparThe Lancet, Volume 379, Issue 9820, 17-23 March 2012, Pg. 1056-1067

[18]. Iosif AM, Sciolla AF, Brahmbhatt K et al. Caregiver Burden in Fragile X Families. Canadian Journal of School Psychology December 2010 vol. 25 no. 4. pg.no. 291-310

[19]. P.J.J. Goossens (2008), 'Family care giving in Bipolar Disorder: Caregiver consequences, caregiver coping styles and caregiver distress. International journal for Social Psychiatry, 54 (4): 303-316.

[20]. Bob Van Wijngaorden, Aart H. Schene (2008), Family care giving in depression: impact on caregiver's daily life, distress and help seeking'. Journal of Affective Disorders, 81 (3): 211-222.

[21]. Anna Kristensson, Ekwall (2007), 'Older Caregivers' coping strategies and sense of coherence in relation to quality of life'. Journal of Advanced Nursing 57 (6): 584-596.

[22]. Annir Steele, Nancy Maruyama (2009). 'Psychiatric symptoms in caregivers of patients with bipolar disorder: A review'. Journal of Affective Disorder. Article in Press.

[23]. N.M.Bhondge, L.H.Sarode, 'Application of t-test to analyze the small sample of Statistical Research' International Journal of Innovations in Engineering and Science, Vol. 2, No.2, 2017 e-ISSN: 2456-3463 